\title{
Organizational Drivers of Innovation: The Role of Workforce Agility
}

\author{
Chiara Franco and Fabio Landini*
}

\begin{abstract}
The interplay between organization practices and innovation is highly relevant in modern business. This paper analyzes whether a specific organizational dimension, namely workforce agility, affects innovative performance. We rationalize this effect within an organizational economics perspective that stresses the role of behavioral motives and skill variety in the innovation process. In particular, we distinguish the contribution of two components: time agility and task agility. Using a sample of nearly 20000 private-sector workplaces in 32 countries, we report conditional correlations between workforce agility and innovation that are consistent with our framework. Establishments with higher workforce agility are more likely to innovate. This relationship holds also when we consider different types of innovation and we distinguish between time and task agility. The analysis of managers' perceptions about internal working climate and information exchange activities suggest that this effect is likely be driven by the fact that workforce agility improves work motivation and knowledge transmission at the workplace level, favouring innovation. Managerial and policy implications are discussed.
\end{abstract}

Keywords: workforce agility, task agility, time agility, innovation

${ }^{*}$ Chiara Franco: University of Pisa; Fabio Landini: University of Parma and ICRIOS-Bocconi University. Contact author: fabio.landini@unipr.it 


\section{Introduction}

In the modern business world, management and organization practices are increasingly recognized as a key drivers of firm innovation. In particular, much attention has been given to activities that relate to different types of work organization, including flexible labour utilization strategies (Wachsen and Blind, 2016, Hoxha and Kleinknecht, 2020), work management systems (Appelbaum et al., 2000) and new human resources management approaches (Laursen and Foss, 2003). In this paper we expand this line of research by focusing on a novel component of work organization that is attributed growing relevance by the management and strategy literature, namely workforce agility.

Firm agility has recently emerged as one of the key organizational paradigm that managers should follow to build sustained competitive advantages. It generally refers to the firm's ability to continuously adjust and adapt strategic direction in a core business (Holbeche, 2018) and it has been declined along several dimensions, including strategic agility (Kosonen and Doz, 2010, Doz, 2020), organizational agility (Teece et al., 2016) and business agility (Lars and Pries-Heje, 2006). Many authors point at agility as key critical business success factor in the modern competitive environment (Doz et al. 2008; CegarraNavarro et al., 2016; Teece et al., 2016). On this basis, research has investigated the drivers of firm agility as well as the competences needed to sustain it (Holbeche, 2018). While this literature has been mostly focused on the relevance of agility for economic performance, few studies provide a rigorous empirical test of this relationship.

Although the popularity of the agility paradigm is large and growing, especially among management consultants, ${ }^{1}$ the academic research on this topic suffers of two limitations. First of all, most of the contributions are based on qualitative analysis of singlecountry and/or single-industry case studies, which fail to provide widely generalizable evidence on the benefits and costs of this approach. Secondly, while there is rising interest in the organizational conditions that must be met for firms to be effectively agile (see, e.g. Carmeli and Dothan, 2017; Doz, 2020, Vecchiato, 2015), less is known about the mechanisms through which agility can actually contribute to performance. With this paper we attempt to make the first steps to fill these gaps.

Our work provides contributions on two sides. First, it adds to management studies investigating the role of firm agility. In particular, we document whether one of its specific component, namely workforce agility, affects innovative performance. Building on Teece et al. (2016) we define workforce agility as the set of practices that an organization use to effectively redeploy its workforce to value creating activities. We consider such practices as a combination of two dimensions: time agility, namely the extent to which firms allow employees to adapt their working time to personal as well as organizational needs; and

${ }^{1}$ See for instance Gary Hamel on agility as the essence of survival available at: https: //www . nbforum. com/nbreport/gary-hamel-agility-is-the-essence-of-survival/ 
task agility, namely whether employees are endowed with the skills to switch tasks among co-workers in response to firm's needs. Alongside a detailed analysis of the effect that both dimensions have on innovative performance, we also discuss and provide indirect evidence about the mechanisms underlying this effect.

Secondly, the paper relates to the empirical works that study organizational and nonR\&D drivers of innovation (Santamaría et al., 2009). On this respect, a growing number of contributions emphasize that alongside standard in-house investments in $R \& D$, different aspects of firm organization have positive effects on innovative performance. The latter are usually distinguished between external factors such as research partnerships (Hagedoorn, 2002), knowledge linkages (D'Este and Iammarino, 2010; D'Este and Patel, 2007, Bozdogan et al., 1998, Rangus and Slavec, 2017), user-producer interactions (Von Hippel, 1986) and open-innovation modes (Chesbrough, 2003; Laursen and Salter, 2006), and internal factors, including management practices (Laursen and Foss, 2003; Haneda and Ito, 2018; Bos-Nehles et al., 2017; Shipton et al., 2006; Beugelsdijk, 2008) and governance structures (Addison et al., 2017; Kraft et al., 2011; Belloc, 2019). The present paper integrates this literature by investigating the innovative contribution of a specific components of firm organization that relates to workforce agility. A novel aspect of our approach is that we exploit detailed information on firm-level time and task organization to derive a composite measure of workforce agility.

In particular, we argue that in hyper-competitive contexts (D'Aveni, 1994) innovation increasingly depends on the firm's ability to integrate and recombine diversified knowledge inputs. In presence of incomplete contracts and dispersed knowledge, workforce agility can contribute to such integration and recombination processes in two ways: first, working time flexibility can trigger dynamics of reciprocal engagement between the employees and the company, favouring group participation and knowledge sharing; second, the possibility to switch tasks among co-workers can reduce boredom and strengthen job interest, stimulating creativity and exchange of ideas within the workplace. The combination of these factors should in turn boost the firm's innovative potential.

We test the validity of these theoretical predictions using unique establishment-level data from the third wave of the European Company Survey (2013), covering nearly 20000 private-sector workplaces located in 32 European countries and providing harmonized information on workforce arrangements, firm hierarchies, and innovation. Specifically, this survey contains specific questions about flexible time arrangements (time agility) and task rotation (task agility). This allows us to obtain a composite measure of workforce agility along these two dimensions. Moreover, the survey provides information about product, process and organizational innovations, alongside a large set of other establishment-level characteristics, such as: size, gender composition, ownership, single vs. multi establishment, position in the value-chain. The availability of such a wealth of information allows us to control for several factors that may affect the relationship between workforce agility 
and innovation.

Overall, the empirical analysis produces results that are highly consistent with our hypotheses. Firm innovative performance, in terms of product, process as well as organizational innovations, is positively associated with workforce agility. We account for the potential endogeneity of workforce agility by exploiting the contractual use of extra pays as an exogenous factor that shifts the probability of organizing workforce in an agile way. Our instrumental variable (IV) estimates reinforce our main findings. Finally, we explore underlying mechanisms that can drive the main results. We document a positive correlation between workforce agility and different measures of knowledge/information sharing as well as managers' perception about good working climate. Taken together, these pieces of evidence suggest that the positive effect of workforce agility on firm innovation is likely be driven by a improvements in work motivation and knowledge transmission that follow the introduction agile management practices.

The remaining of the paper is organized as follows. In Section 2, we introduce our theoretical framework. In Section 3, we describe the data and the key variables used in the empirical analysis, whose results are presented in Section 4 . Section 5 concludes.

\section{Theoretical framework}

\subsection{Overview}

At the theoretical level, two premises help to characterize the contribution that management practices, and more specifically workforce agility, can offer to the innovation process. First, innovation is a complex endeavour that depends on knowledge as one of its primary inputs. Second, knowledge, especially in its tacit form, is a dispersed and diversified input whose main carriers are individuals working inside and outside firms. On this ground, one of the main tasks of innovative firms is to design formal and informal mechanisms that enable the integration and recombination of such diversified knowledge inputs and orient them towards value creation activities. In the literature, such mechanisms have been broadly associated with the concepts of routines (Nelson and Winter, 1982), capabilities (Richardson, 1972) and dynamic capabilities (Teece et al., 1997). Despite some conceptual differences, all these approaches share a common emphasis on the relevance of experiential, localized, socially constructed and embedded knowledge as a key driver of firm innovation (Foss, 2003).

Following these approaches, economists and business scholars have devoted growing attention to specific managerial interventions that help firms to improve their innovative performance. This is the case, for instance, for so-called new human resource management practices, which encompass "a host of contemporary changes in the organization of the employment relation, referring to team-based organization, continuous (often team- 
based) learning, decentralization of decision rights and incentives, emphasis on internal knowledge dissemination, etc." (Laursen and Foss, 2003, p. 248). Such practices can be conductive to innovation activity for a number of reasons: they improve the discovery and utilization of localized knowledge (Hayek, 1945; Jensen and Meckling, 1995), they favour the recombination of different human resource inputs (Karim and Kaul, 2015), and they generally stimulate knowledge diffusion within firms (Ortega, 2001). Several works indeed provide empirical evidence showing a positive effect of new human resources management practices on innovation (e.g., Laursen and Foss, 2003; Shipton et al., 2006; Foss et al., 2011, Santangelo and Pini, 2011).

Building on this literature, a recent stream of research stresses the role of organizational agility as a driver of firm competitiveness and innovation. Agile firms are generally described as firms that can quickly adapt their organization to sustain competitive advantages in turbulent and fast changing market environments (Teece et al., 2016). In the agility paradigm, speed and flexibility of responses are considered key requirements that enable firms to stay ahead of competitors (Holbeche, 2018). On this ground, several contributions investigate the factors that allow firms to effectively meet these requirements. Carmeli and Dothan (2017), for instance, focuses on the role of generative work spaces and show that the latter indeed improve organizational agility, i.e. how quickly an organization transforms a conception into a product that is ready for the market. Doz (2020) links the ability to respond successfully to external changes (i.e., strategic agility) to the coherence among skills and behaviours of senior executives, which favor the smooth and prompt adaptation of management practices. Vecchiato (2015) stresses instead the importance of corporate foresight, which is considered one of the main levers of agility-induced value creation.

Although rich and variegated (for a detailed review on the workforce/organizational dimension see Muduli, 2013), the agility literature still lacks a critical scrutiny of the actual mechanisms through which agility should indeed contribute to firm performance. In most of the contributions the virtue of agility are taken as given and the latter is itself treated as a direct synonym of good performances. This is true especially when we take into account the innovative side of economic performance, which is largely acknowledged as a key driver of today's business value. In sum, there is clearly a rising theoretical and empirical understanding of the relevance of organizational agility for firm competitiveness, but that understanding need to be integrated with more focused theoretical and empirical investigations on the mechanisms through which agility promote innovation. This is precisely the aim of the next section. 


\subsection{How workforce agility can promote innovation}

To repeat, we define workforce agility as the capacity of an organization to effectively and efficiently redeploy/redirect its workforce to value creating activities, especially innovation 2 . On this basis, we identify two main channels through which workforce agility can contribute to innovation: the first channel concerns the organization of working time and can be labelled time agility; the second channel refers to the organization of tasks that employees carry out inside firms and can be labelled task agility. For both dimensions we hypothesize a positive effect on innovative performance, which is strengthen by the key role that human resources play in today's innovation process (Beugelsdijk, 2008).

With respect to the working time dimension, we interpret time agility as the opportunity offered to employees to adapt the time of their daily work to personal needs or wishes. This opportunity is usually associated with the presence of flexible time arrangements, such as flexi-time and working-time accounts. Recent studies have documented a positive association between flexible time arrangements and productivity (Bloom et al. 2015, Beckmann, 2016). Theoretically, this effect can be driven either by an increase in individual or organizational productivity, or by the fact that flexible time arrangements improve employee well-being and job-life balance, favouring long-term engagement with the company and leading to higher investments in firm-specific skills and human capital (Golden, 2011). When applied to the case of innovation, the positive contribution of time agility can be rationalized within a standard gift exchange framework (Fehr et al., 1998; Kube et al., 2012). In presence of incomplete contracts and dispersed knowledge, practices that give employees more working time flexibility affect innovation because employees are more willing to share their private knowledge in exchange for working in a more supportive environment. Such shared knowledge may in turn improve the firm's ability to grasp innovation opportunities ahead of competitors, thus fostering innovative performance. Cummings (2004) and Lin (2007) indeed show that knowledge sharing among co-workers positively contribute to innovation.

Alongside its working time dimension, workforce agility can affect innovation via the organization of tasks inside the firm. In this study we interpret task agility as the ability of employees to switch tasks among co-workers in response to organizational needs. Researchers in the field of human resource management and personnel economics have long recognized the importance of exposition to a broad ranges of perspectives and information as a driver of creativity and innovation Nonaka and Takeuchi, 1995, Kang et al., 2007). Through experiencing variety in their daily tasks, employees may be less

\footnotetext{
${ }^{2}$ This definition share some similarities with concept of workplace flexibility as defined by Hill et al. (2008), i.e. 'the ability of workers to make choices influencing when, where, and for how long they engage in work-related tasks'. Both definitions consider changes and adaptations of workers' activities as an inherent feature of workplaces. However, while Hill et al. (2008) take a worker perspective on the issue of flexibility, we adopt an organizational perspective that stresses the ability of the organization as a whole to adapt rapidly to changing demand and supply.
} 
likely to oppose to changes and new ideas and willing to at least consider their potential benefits (Shipton et al., 2006). Moreover, the possibility to perform different tasks within teams favours processes of intraorganizational knowledge recombination, which are found to promote innovation (Karim and Kaul, 2015). Finally, some authors argue that job rotation and teamwork can increase motivation by reducing employees' boredom and keeping them interested in their job (Coşgel and Miceli, 1999). High motivation and job interest are in turn considered key preconditions for creativity and innovation at the workplace level (Fischer et al. 2019). All things together, we thus expect firms adopting practices that stimulate task agility, be it through task rotation and/or teamwork, to have better innovative performance than firms that do not.

To sum up, our mainly theoretical hypothesis is that higher workforce agility, considered along both its working time and task dimensions, is associated with better knowledge sharing and knowledge recombination among co-workers, stronger employee' engagement and motivation and lower resistance to change and new ideas. Altogether, these factors should positively affect firm innovation.

\section{Data and variables}

\subsection{The European Company Survey: overview}

To test the effect of workforce agility on firm innovation we use establishment-level data from the third wave of the European Company Survey (ECS 2013). ECS data cover a representative sample of non-agricultural establishments employing at least 10 employees and located in 32 countries (27 EU Member States and Croatia, Former Yugoslav Republic of Macedonia, Iceland, Montenegro and Turkey). A crucial advantage of this survey is that it provides harmonized cross-country information on management practices and organizational design at the workplace level. Moreover, it contains information on whether the establishment has introduced any new product/service, process, and/or organizational change. The survey is conducted in two steps. The first step involves a telephone interview with a manager, who is asked about establishment characteristics, organizational practices (e.g. compensation policies, working-time arrangements, etc), and industrial relations. The second stage comprises an interview with an employee representative in those establishments in which an employee representation structure is present. As information obtained in the second stage is conditional on having an employee representation structure, our analysis is exclusively based on the information gathered in the management questionnaire. 


\subsection{Main variables}

\subsubsection{Dependent variables}

We use three different dependent variables accounting for the type of innovation the establishment carries out:

1. Product innovation: dummy variable that is equal 1 if the manager of the establishment replied "yes" to the question: "Since the beginning of 2010 has this establishment introduced any new or changed products or services (either internally or externally)?"

2. Process innovation: dummy variable that is equal 1 if manager of the establishment replied "yes" to the question: " Since the beginning of 2010 has this establishment introduced any new or significantly changed processes, either for producing goods or supplying services?"

3. Organizational innovation: dummy variable that is equal 1 if the manager of the establishment replied "yes" to the question: "Since the beginning of 2010 has this establishment introduced any organizational change?"

\subsubsection{Independent variables: Workforce agility}

Our main independent variable is the one measuring workforce agility which is built summing up the values of two variables:

1. Time agility: categorical variable ranging from 1 to 7 , as the answer to the question "Approximately what percentage of employees have the possibility to adapt - within certain limits - the time when they begin or finish their daily work according to their personal needs or wishes?". Possible answers are: "none at all", "less than 20\%", "20\% to 39\%", "40\% to $59 \%$ ", "60\% to $79 \%$ ", " $80 \%$ to $99 \%$ ", "all".

2. Task agility: sum of two categorical variables ranging from 1 to 3 . The first variable measures the degree of task rotation. The manager of the establishment has to answers to the question "Do any of the employees at this establishment rotate tasks with other employees". Possible answers include: "no, none do" or "no, the high level of required skills or expertise prevents employees from rotating tasks" "? "yes, some do", "yes, most do". The second variable measures the extent to which employees work in teams made up of many people working together, answering to this question: "Do you have any teams in your establishment". Possible answers are: "no", "yes, most of them work in a single team", "yes, most of them work in more than one team".

The sum of time agility and task agility gives us a composite measure of workforce agility, which is a categorical variable ranging from 3 to 13 .

\footnotetext{
${ }^{3}$ They both belong to category 1
} 


\subsubsection{Independent variables: control variables}

We also include in our empirical exercise some establishment level controls to account for the characteristics of the workforce: the percentage of employees who are older than 50 years (old workforce), the percentage of female (women) and the percentage of workers having a university degree (high education). All these items are included in the analysis as categorical variables ranging from 0 to 3 ("less than $20 \%$ " or "none at all", "20\% to 39\%", "40\% to 59\%", "more than 59\%"). We also consider variables that can account for the variation of innovation activities of the establishment. The first one is represented by a variable capturing the establishment's ability to monitor possible external knowledge sources (external search), which takes the form of a dummy equal 1 if the manager replied "yes, using staff assigned specifically to this task" to the question "Does this establishment monitor external ideas or technological developments for new or changed products, processes or services?". Another related variable (past technological change) captures the changes in the use of technology that have taken place within the establishment during the last three years (dummy equal 1 if the manager replied "yes" to the question listing "changes in technology use" among the changes occurring at the workplace since the beginning of 2010). Finally, we include a set of variables that control for establishment-specific characteristics. First, a dummy variable (information system) equal 1 if the manager replied "yes" to a question related to the use of specific types of information-related systems of production ("Does this establishment use information systems to minimize supplies or work-in- process? These are sometimes known as justin-time or lean production systems or as working according to a zero buffer principle".) Second, a variable capturing the financial health of the establishment (worse finance): it is a dummy equal 1 if the manager replied "worsened" to the question "Since the beginning of 2010, has the financial situation of this establishment...". Third, a variable that accounts for the existence of outsourcing-related practices (outsourcing): it is a dummy equal 1 if the manager replied "Production of goods and services" to the question "Is this establishment partly or entirely outsourcing each of the following activities (this activity) to a third party that is not owned by your establishment or the company you belong to? $"$

\subsection{Descriptive statistics}

Before turning to analyse the results of our empirical exercise, we provide some descriptive statistics of our sample, mainly to characterize the behavior of the dependent and our main independent variables. Mean, standard deviation and range of variation for the variables included in our analysis are reported in Table 1.

Figure 1 shows the country-level workforce agility scores from all the observations in our data. Nordic countries, such as Finland and Sweden, are those that show the 
highest values, followed by Luxembourg, Slovenia, Austria and Denmark. At the bottom of the hierarchy are countries in southern Europe such as Cyprus and Greece, along with Balkan and eastern European countries like Croatia, Montenegro, Poland, Bulgaria as well as Turkey. In one sense this cross-country ranking is not surprising, since it approximates the cross-country productivity ranking. Although we are far from establishing any causal relationship, it is certainly plausible that, within our theoretical framework, workforce agility positively affects national productivity. A regression of GDP per capita on workforce agility across the sample of 32 countries yields a strong positive correlation with an R-squared of 0.40 . Thus, the contribution of workforce agility to country-level economic performance appears to be potentially qualitatively important.

Interestingly, workforce agility exhibits high heterogeneity within countries. Figures 2 and 3 report the firm-level histogram of workforce agility by country. For the ease of comparison we also report in each graph the probability density function of the standard Normal distribution. In most countries workforce agility has a distribution that is skewed towards low values, with few exceptions such as Finland and Sweden where skeweness points in the opposite direction. In some contexts, such as Italy, Luxembourg and Spain, within-country heterogeneity is particularly high, with histograms that approximate a bimodal distribution. Overall, the existence of heterogeneity in workforce agility is consistent with previous country-level evidence on other types of management practices as documented by Bloom and Van Reenen (2010, 2007).

To have a first look at relationship between innovation and workforce agility we include in Figure 4 country maps that are colored depending on the intensity of the two variables. Innovation is measured as the country-level weighted average of any new product, process or organizational change introduced by the establishments. Visual inspection suggests that the two variables move together. Nordic countries exhibit higher workforce agility and innovation scores than the block of south-eastern European countries. Moreover, there is a group of southern and continental countries such as Italy, Spain, France and the Netherlands in which the value of both variables is close to the sample mean. The existence of a positive correlation between innovation and workforce agility is confirmed also in a cross-country regression (coeff. 0.043, p-value $=0.056$ ). Altogether, this preliminary evidence supports our main research hypotheses.

In our theoretical framework the contribution of workforce agility to innovative performance has a strong behavioural root, in the sense that it depends on the degree of cooperation among workers. It is therefore reasonable to expect that the relationship between the two variables is stronger in countries where social norms that favour cooperation are more widespread. To check whether this is indeed the case, we run a validation exercise where we split the countries in two groups depending on the perceived level of trust. Then, we correlate country-level innovation and workforce agility scores in the two groups separately. Result are reported in Figure 5. While in countries with high 
trust innovation and workforce agility are positively correlated (Pearson's coeff. 0.568, p-value $<0.01$ ), in low trust countries they are not. This result is in line with our expectations and it suggests that our measure of workforce agility indeed capture the effect of social interactions taking place within workplaces.

Lastly, Figure 6 reports the results of an exercise where we compare the mean difference in workforce agility between innovative and non-innovative establishments across several establishment-level dimensions, such as: size (panel a); workforce age (panel b); workforce skills (panel c); and types of labor contract (panel d). In all the cases, innovative establishments exhibit higher workforce agility scores than non-innovative ones. This result suggests that the positive association between innovation and workforce agility holds irrespective of establishment-specific factors that may potentially mediate this effect. Obviously, a rigorous test on the validity of this interpretation requires a more elaborated multivariate analysis, which we now turn to.

\section{Results}

\subsection{Baseline model}

Our empirical analysis is carried out estimating a probit model as the dependent variable is always a dummy. In all regressions, besides our main independent variable, that is workforce agility, we introduced further control variables previously described, that account both for organizational features of the establishment as well as socio-demographic characteristics of the employees. Moreover, we include dummies to account for the size of the establishment, the industry to which it belongs and the country.

In Table 2 our benchmark regressions are shown. In the first column, where the dependent variable represents the ability to carry out any type of innovation activity, we see that control variables have the expected signs and significance. Larger establishments and those endowed with a monitoring capability of the external knowledge, as well those employing young and highly skilled employees are those that have higher probability of innovation. This is so also for the establishments that have introduced changes in the use of technology as well as for those that rely on just-in-time or lean production systems and outsourced part of the production to a third party; instead, when the financial situation of the establishment has worsened during the last three years we observe a negative effect on innovative performance. The signs and significance level of the control variables are quite robust even when other dependent variables, describing whether the establishment has introduced product (column 2), process (column 3) or organization innovation (column 4), are used.

With respect to our main independent variable we see that it is positive and highly significant in all models, pointing out that coherently with our hypotheses, higher level 
of workforce agility is positively associated with better innovative performance. Confirmatory results are found also for product, process as well as organizational innovation, even though marginal effects (not reported in the table) are different in the three cases. The lowest value is the one for organizational innovation (0.009), and the highest value the one for process innovation (0.013).

From column 5 to 8 we run the same regression as in columns 1-4 but considering as separate the two dimensions of task agility and time agility. We find that both variables positively contribute to the innovative performance of the establishment, independently of the type of innovation that is introduced. However, as before, when calculating the marginal effects we can see that a greater role is played by task agility, as its value (between 0.027 and 0.031 , depending on the type of innovation) is always higher than the one of time agility (between 0.006 and 0.007 ). This stands for the fact that having experienced higher task rotation can generate more behavioural flexibility that can easily translate into enhanced innovation activities. Overall, these results provide strong support for our theoretical hypotheses. ${ }^{4}$

\subsection{Endogeneity}

Conditional correlations presented in Table 2 suggest a positive association between workforce agility and innovative performance. However, we are concerned about the potential endogeneity bias of our estimates. For example, there may an unobservable variable that is correlated with both innovation and workforce agility. To deal with this we consider an instrumental variable (IV) strategy for workforce agility, grounding the identification of a plausible instrument on the institutional determination of payment schemes. Even though identification is only imperfect and we cannot interpret the outcomes as plainly causal relationships, we are more confident about the validity of our results when they are robust to an IV specification. We believe we cannot do much more to improve the identification of a causal effect given institutional setting and the available data.

As documented by Breu et al. (2002) and Van Oyen et al. (2001), workforce agility is often associated with organizational practices characterized by highly decentralized decision-making and weak (if any) monitoring. The reason is that in these contexts activities related to hierarchical coordination and metering of effort can be very expensive. On the other hand, the lack of managerial monitoring exposes firms to the risk that employees shirk on their effort and it thus require firms to adopt alternative solutions to avoid it (Holmstrom and Milgrom, 1987). One factor that can serve this purpose is the introduction of a well-designed system of incentives: labour contracts that foresee some

\footnotetext{
${ }^{4}$ As a further robustness check we run a model in which the dependent variable accounts for the fact that the establishment can carry out both product and process innovation, as well as all the three types of innovation (including organizational innovation) at the same time. The results (available from the authors upon request) are in line with the ones of the benchmark estimates.
} 
kind of (individual and/or team) incentive pay on the top of standard fixed wages can indeed favour the alignment of employees' interest with the ones of the company, limiting issues related to shirking even in the absence of close monitoring (Lazear, 1995). It follows that in presence of incentive-based employment contracts the adoption of human resources management practices fostering workforce agility tends to be easier.

At the same time, it is possible to argue that the adoption of incentive-based labour contract has strong institutional roots. Barth et al. (2008), for instance, document that performance pay, while being motivated by agency problems, tends to be more common in less unionized firms and in contexts in which wage-setting institutions allow for decentralized bargaining. Along the same lines, the literature studying the variety of institutional settings across countries shows that the presence of flexible-reward system is complementary to other types of institutions such as the ones regulating dismissal protections in the labour market (Hall and Soskice, 2001). Moreover,Arrowsmith and Marginson $(\overline{2010})$ report suggestive evidence that the evolution of the competitive environment is more relevant than the focus on pay itself to explain changes in the adoption of variable payments system. Overall, these contributions suggest that the introduction of incentive-based payments is highly influenced by the institutional context in which firms operate. We are thus inclined to consider the presence of such incentives as a relatively exogenous (i.e. contextually determined) factor that shifts the chances of relying on workforce agility.

Specifically, we build a variable that is the sum of four dummy variables: they all refer to questions referring to whether some variable payment options, on top of basic pay, are in place in the establishment of the respondent. In particular, dummies are equal 1 if the following payment scheme are in use: "Payment by results, for example piece rates, provisions, brokerages or commissions" , "Variable extra pay linked to the individual performance following management appraisal", "Variable extra pay linked to the performance of the team, working group or department", "Variable extra pay in form of share ownership scheme offered by the company". We use their sum to instrument for workforce agility.

The results are collected in Table 3. Consistent with our priors, the first-stage results show that incentive pay schemes correlate positively with workforce agility confirming it is a good instrument. The Wald test of exogeneity is always significant at $1 \%$ level, which suggests the need to account for the endogeneity of our variable of interest. When entered in the innovation regressions, the coefficients of the instrumented workforce agility has sign and significance coherent with our baseline regressions. In particular, we confirm that workforce agility positively correlates with all types of innovation..$^{5}$

\footnotetext{
${ }^{5}$ The magnitude of the effect is larger than in the baseline estimates. This could be due to measurement error in our indicator of workforce agility. Moreover, baseline estimates could also be downward biased if an omitted determinant of innovative performance is negatively correlated with workforce agility. For example, new technologies may be associated with an increase in skill polarization (Michaels et al. 2014), which in turn may make the adoption of agile workforce management practices associated task
} 


\subsection{Mechanisms}

In order to dig deeper into the mechanisms through which workforce agility can impact on innovation activities we run some regressions where we consider as dependent variables other establishment level characteristics that can account for different channels through which the observed effect can occur. In our theoretical framework, we argued that workforce agility can strengthen innovation by favouring mutual knowledge exchanges among workers. We thus exploit the large variety of information available in our data and include in the analysis variables that account for the presence or the willingness to build, within the boundaries of the establishment, a climate of mutual trust and knowledge sharing between managers and employees.

In particular they refer to the whether the general working climate is considered good or very good, whether the percentage of employees that received paid time-off from their normal duties to undertake training is at least 60 , whether practices associated with the exchange of information are active within the establishment, in the form of: regular staff meetings that are open to all employees; dissemination of information through newsletters, website, notice boards, email etc; suggestion schemes (i.e. the collection of ideas and suggestions from the employees, voluntary and at anytime, traditionally by means of a 'suggestion box'); and survey among employees. All these variable are introduced into the model as dummy variables and regressed against workforce agility together with the other variables used in the benchmark specification to account for workforce composition as well as industry and country fixed effects.

The results of this empirical exercise are reported in Table 4. Each column refers to a different dependent variable among the ones described above. In all models, the coefficient of workforce agility is positive and significant. This suggests that, in line with our priors, establishments with higher workforce agility are more likely to be characterized by socially engaging working environments. In the latter, employment relations are of relatively high quality, workers are motivated and frequently engaged in activities that favour knowledge exchanges. Altogether, these factors may crowd in intrinsic motivation to work as well as creativity, which can in turn contribute to the innovation process.

\section{Conclusions}

In this study we investigated the role of workforce agility in sustaining innovative performance. We studied its impact using an organizational economics perspective that stresses the relevance of behavioral motives and skill variety in the innovation process. In particular, using a cross-country establishment-level dataset for the year 2013, we docu-

rotation more difficult to implement. In other words, the co-existence of highly and low-educated workers may make it more difficult to organize workforce within the agility framework. 
mented that the degree of agility in the organization of the workforce, measured as the combination of task and time agility, is a crucial determinant of innovation.

More in detail, our results showed that firms characterized by higher degree of workforce agility exhibit higher probabilities of introducing any type of innovation. The magnitude of the impact is different depending on the type of innovation, being the highest for process innovation. We further showed that disentangling the two components of workforce agility both the dimensions of time and task agility significantly impact on innovation activities, even though to a different extent. In particular, the role of task agility seems to be the most important to drive the final effect on innovation. Finally, as hypothesized in our theoretical framework, we documented that the positive association between innovation and workforce agility is likely be driven by differences in the quality of employment relationships and knowledge exchange practices that characterize agile and non-agile firms.

It is worth acknowledging some limitations of our study. First, the structure of the data does not allow us to obtain a sharp econometric identification. This is a common limitation in most of the literature studying the economic effect of management and organization practices, including firm agility. We are reassured of the validity of our results because a consistent picture emerges when using different estimation strategies. Moreover, compared to previous studies on organizational agility, we rely on a much larger and heterogeneous dataset, which strengthens the external validity of our results. However, further research will have to put the positive association between innovation and workforce agility under stricter causal scrutiny. Second, the lack of establishment-level information about additional factors that are usually associated with the agility paradigm, for instance the ability to change and adjust the competitive strategy in a core business, forces us to focus on the innovative contribution of a specific component of agility that relates to the organization of the workforce. Future research will have to verify whether our results hold also when employing a more encompassing view of organizational agility.

Our results have important implications for both managers and policy makers. As for the former, they provide further evidence that also non-R\&D factors, such as organization practices and in particular workforce agility, are important drivers of innovation. Although this result tends to be true in general, the magnitude of the effect may depend on the type of innovation (i.e. it is stronger for process innovation than for the other types of innovation) and the organizational dimension taken in into account (i.e. it is stronger for task agility than for time agility). These results can provide useful insights for managers wishing to improve the innovative performance of their company through organization. In particular, they can be highly relevant for those managing small firms, which usually attribute great relevance to organizational drivers of innovation, lacking financial resources to invest in R\&D (Rammer et al., 2009).

Moreover, the results of our analysis can contribute to policy discussions about work 
organization. In fact, while some aspects of workforce agility are clearly a discretionary choice of the managers - think for instance about the decision to rely on job designs that involve task agility, others, such as the possibility to implement flexible time arrangements, require adequate legal and contractual framework. Policy makers should thus engage with employer and employee associations (e.g. business representatives and trade unions) to design a system of industrial relations that take qualitative aspects of the employment relationships such as agile time arrangements into greater account. 


\section{References}

Addison, J.T., Teixeira, P., Evers, K., Bellmann, L., 2017. Collective bargaining and innovation in Germany: a case of cooperative industrial relations? Industrial Relations $56,73-121$.

Appelbaum, E., Bailey, T., Berg, P., Kalleberg, A.L., Bailey, T.A., 2000. Manufacturing advantage: Why high-performance work systems pay off. New York: Cornell University Press.

Arrowsmith, J., Marginson, P., 2010. The decline of incentive pay in British manufacturing. Industrial Relations Journal 41, 289-311.

Barth, E., Bratsberg, B., Hægeland, T., Raaum, O., 2008. Who pays for performance? International Journal of Manpower 29, 8-29.

Beckmann, M., 2016. Working-time autonomy as a management practice. IZA World of Labor .

Belloc, F., 2019. Institutional complementarities between labour laws and innovation. Journal of Institutional Economics 15, 235-258.

Beugelsdijk, S., 2008. Strategic human resource practices and product innovation. Organization Studies 29, 821-847.

Bloom, N., Liang, J., Roberts, J., Ying, Z.J., 2015. Does working from home work? Evidence from a Chinese experiment. The Quarterly Journal of Economics 130, 165218.

Bloom, N., Van Reenen, J., 2007. Measuring and explaining management practices across firms and countries. Quarterly Journal of Economics 122, 1351-1408.

Bloom, N., Van Reenen, J., 2010. Why do management practices differ across firms and countries? Journal of Economic Perspectives 24, 203-24.

Bos-Nehles, A., Renkema, M., Janssen, M., 2017. HRM and innovative work behaviour: A systematic literature review. Personnel Review 46, 1228-1253.

Bozdogan, K., Deyst, J., Hoult, D., Lucas, M., 1998. Architectural innovation in product development through early supplier integration. R\&D Management 28, 163-173.

Breu, K., Hemingway, C.J., Strathern, M., Bridger, D., 2002. Workforce agility: the new employee strategy for the knowledge economy. Journal of Information Technology 17, 21-31. 
Carmeli, A., Dothan, A., 2017. Generative work relationships as a source of direct and indirect learning from experiences of failure: Implications for innovation agility and product innovation. Technological Forecasting and Social Change 119, 27-38.

Cegarra-Navarro, J.G., Soto-Acosta, P., Wensley, A.K., 2016. Structured knowledge processes and firm performance: The role of organizational agility. Journal of Business Research 69, 1544-1549.

Chesbrough, H.W., 2003. Open innovation: The new imperative for creating and profiting from technology. Cambridge, MA: Harvard Business Press.

Coşgel, M.M., Miceli, T.J., 1999. Job rotation: Cost, benefits, and stylized facts. Journal of Institutional and Theoretical Economics 155, 301-320.

Cummings, J.N., 2004. Work groups, structural diversity, and knowledge sharing in a global organization. Management Science 50, 352-364.

D'Aveni, R.A., 1994. Hypercompetition: managing the dynamics of strategic Maneuvering. New York: Free Press.

D'Este, P., Iammarino, S., 2010. The spatial profile of university-business research partnerships. Papers in Regional Science 89, 335-350.

D'Este, P., Patel, P., 2007. University-industry linkages in the UK: What are the factors underlying the variety of interactions with industry? Research Policy 36, 1295-1313.

Doz, Y., Doz, Y.L., Kosonen, M., 2008. Fast strategy: How strategic agility will help you stay ahead of the game. Harlow, U.K.: Pearson Education.

Doz, Y.L., 2020. Fostering strategic agility: How individual executives and human resource practices contribute. Human Resource Management Review 30, 100693.

Fehr, E., Kirchler, E., Weichbold, A., Gächter, S., 1998. When social norms overpower competition: Gift exchange in experimental labor markets. Journal of Labor Economics $16,324-351$.

Fischer, C., Malycha, C.P., Schafmann, E., 2019. The influence of intrinsic motivation and synergistic extrinsic motivators on creativity and innovation. Frontiers in Psychology $10,137$.

Foss, N.J., 2003. Bounded rationality and tacit knowledge in the organizational capabilities approach: an assessment and a re-evaluation. Industrial and Corporate Change $12,185-201$. 
Foss, N.J., Laursen, K., Pedersen, T., 2011. Linking customer interaction and innovation: The mediating role of new organizational practices. Organization Science 22, 980-999.

Golden, L., 2011. The effects of working time on productivity and firm performance: a research synthesis paper. Conditions of Work and Employment Series - ILO 33.

Hagedoorn, J., 2002. Inter-firm R\&D partnerships: an overview of major trends and patterns since 1960. Research Policy 31, 477-492.

Hall, P.A., Soskice, D., 2001. Varieties of Capitalism: The Institutional Foundations of Comparative Advantage. Oxford: Oxford University Press.

Haneda, S., Ito, K., 2018. Organizational and human resource management and innovation: Which management practices are linked to product and/or process innovation? Research Policy 47, 194-208.

Hayek, F.A., 1945. The use of knowledge in society. American Economic Review 35, $519-530$.

Hill, J.E., Grzywacz, J.G., Allen, S., Blanchard, V.L., Matz-Costa, C., Shulkin, S., PittCatsouphes, M., 2008. Defining and conceptualizing workplace flexibility. Community, Work and Family 11, 149-163.

Holbeche, L., 2018. The Agile Organization: How to Build an Engaged, Innovative and Resilient Business. London, UK: Kogan Page Publishers.

Holmstrom, B., Milgrom, P., 1987. Aggregation and linearity in the provision of intertemporal incentives. Econometrica 55, 303-328.

Hoxha, S., Kleinknecht, A., 2020. When labour market rigidities are useful for innovation. Evidence from German IAB firm-level data. Research Policy 49, 104066.

Jensen, M.C., Meckling, W.H., 1995. Specific and general knowledge, and organizational structure. Journal of Applied Corporate Finance 8, 4-18.

Kang, S.C., Morris, S., Snell, S., 2007. Relational archetypes, organizational learning, and value creation: Extending the human resource architecture. Academy of Management Review 32, 236-256.

Karim, S., Kaul, A., 2015. Structural recombination and innovation: Unlocking intraorganizational knowledge synergy through structural change. Organization Science 26, 439-455.

Kosonen, M., Doz, Y.L., 2010. Embedding strategic agility: A leadership agenda for accelerating business model renewal. Long Range Planning 43, 370-382. 
Kraft, K., Stank, J., Dewenter, R., 2011. Co-determination and innovation. Cambridge Journal of Economics 35, 145-172.

Kube, S., Maréchal, M.A., Puppe, C., 2012. The currency of reciprocity: Gift exchange in the workplace. American Economic Review 102, 1644-62.

Lars, M., Pries-Heje, J., 2006. Business agility and diffusion of information technology. European Journal of Information Systems 15, 116-119.

Laursen, K., Foss, N.J., 2003. New human resource management practices, complementarities and the impact on innovation performance. Cambridge Journal of Economics $27,243-263$.

Laursen, K., Salter, A., 2006. Open for innovation: the role of openness in explaining innovation performance among UK manufacturing firms. Strategic Management Journal 27, 131-150.

Lazear, E.P., 1995. Personnel Economics. Cambridge, MA: MIT press.

Lin, H.F., 2007. Knowledge sharing and firm innovation capability: an empirical study. International Journal of Manpower 28, 315-332.

Michaels, G., Natraj, A., Van Reenen, J., 2014. Has ict polarized skill demand? evidence from eleven countries over twenty-five years. The Review of Economics and Statistics $96,60-77$.

Muduli, A., 2013. Workforce agility: a review of literature. IUP Journal of Management Research 12, 55-65.

Nelson, R., Winter, S., 1982. An Evolutionary Theory of Economic Change. Cambridge, MA: Belknap Press.

Nonaka, I., Takeuchi, H., 1995. The knowledge creating company: How Japanese companies create the dynamics of innovation. New York: Oxford University Press.

Ortega, J., 2001. Job rotation as a learning mechanism. Management Science 47, 13611370.

Rammer, C., Czarnitzki, D., Spielkamp, A., 2009. Innovation success of non-R\&Dperformers: substituting technology by management in SMEs. Small Business Economics $33,35-58$.

Rangus, K., Slavec, A., 2017. The interplay of decentralization, employee involvement and absorptive capacity on firms' innovation and business performance. Technological Forecasting and Social Change 120, 195-203. 
Richardson, G.B., 1972. The organisation of industry. Economic Journal 82, 883-896.

Santamaría, L., Nieto, M.J., Barge-Gil, A., 2009. Beyond formal R\&D: Taking advantage of other sources of innovation in low-and medium-technology industries. Research Policy $38,507-517$.

Santangelo, G.D., Pini, P., 2011. New HRM practices and exploitative innovation: A shopfloor level analysis. Industry and Innovation 18, 611-630.

Shipton, H., West, M.A., Dawson, J., Birdi, K., Patterson, M., 2006. HRM as a predictor of innovation. Human Resource Management Journal 16, 3-27.

Teece, D., Peteraf, M., Leih, S., 2016. Dynamic capabilities and organizational agility: Risk, uncertainty, and strategy in the innovation economy. California Management Review 58, 13-35.

Teece, D.J., Pisano, G., Shuen, A., 1997. Dynamic capabilities and strategic management. Strategic Management Journal 18, 509-533.

Van Oyen, M.P., Gel, E.G., Hopp, W.J., 2001. Performance opportunity for workforce agility in collaborative and noncollaborative work systems. IIE Transactions 33, 761777.

Vecchiato, R., 2015. Creating value through foresight: First mover advantages and strategic agility. Technological Forecasting and Social Change 101, 25-36.

Von Hippel, E., 1986. Lead users: a source of novel product concepts. Management Science 32, 791-805.

Wachsen, E., Blind, K., 2016. More labour market flexibility for more innovation? Evidence from employer-employee linked micro data. Research Policy 45, 941-950. 


\section{Figures and Tables}

Figure 1: Workforce agility across countries.

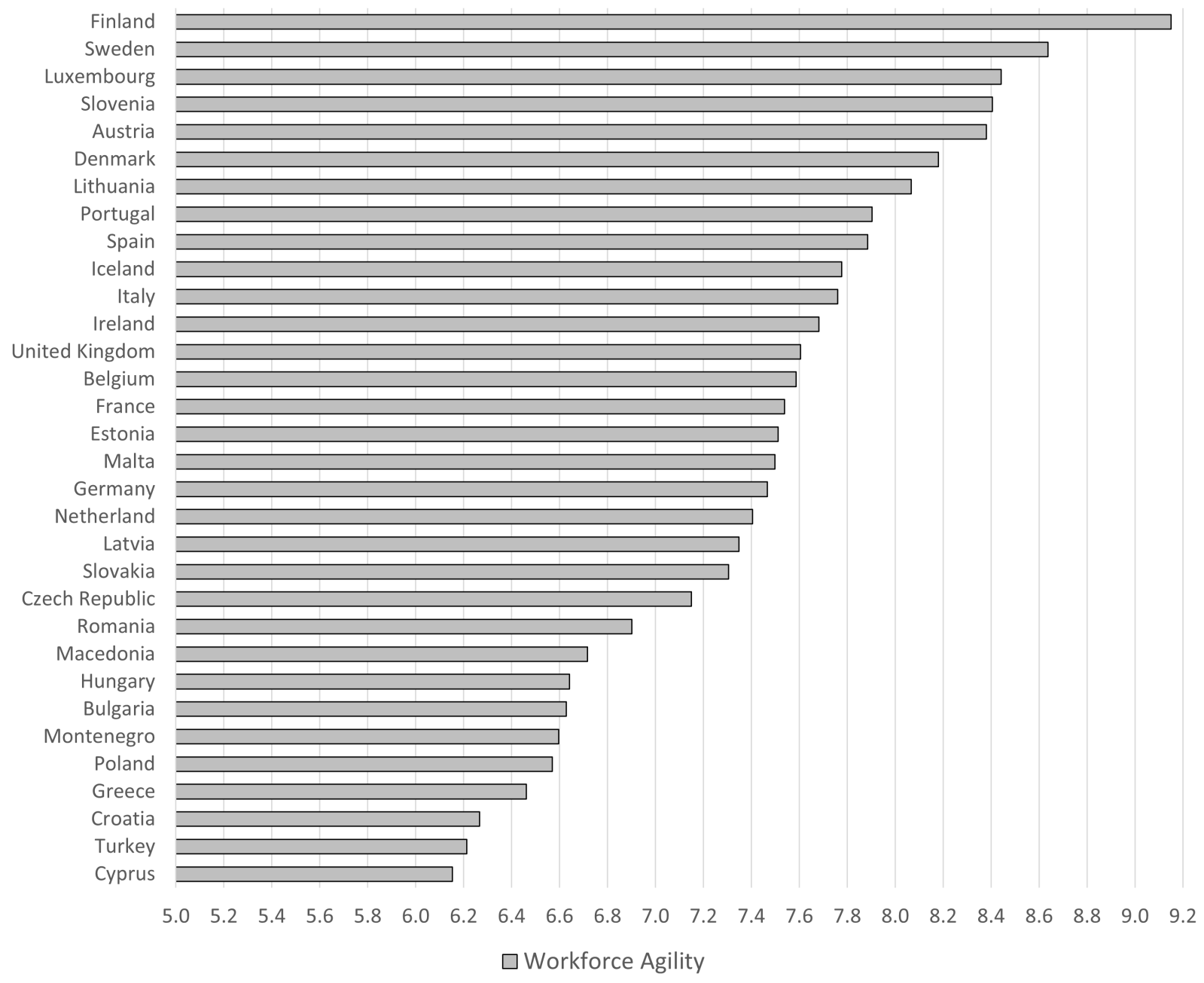

Notes: Pooled data from the European Company Survey 2013. Averages are taken across all firms within each country using sample weights. 
Figure 2: Heterogeneity of workforce agility across countries (first group).
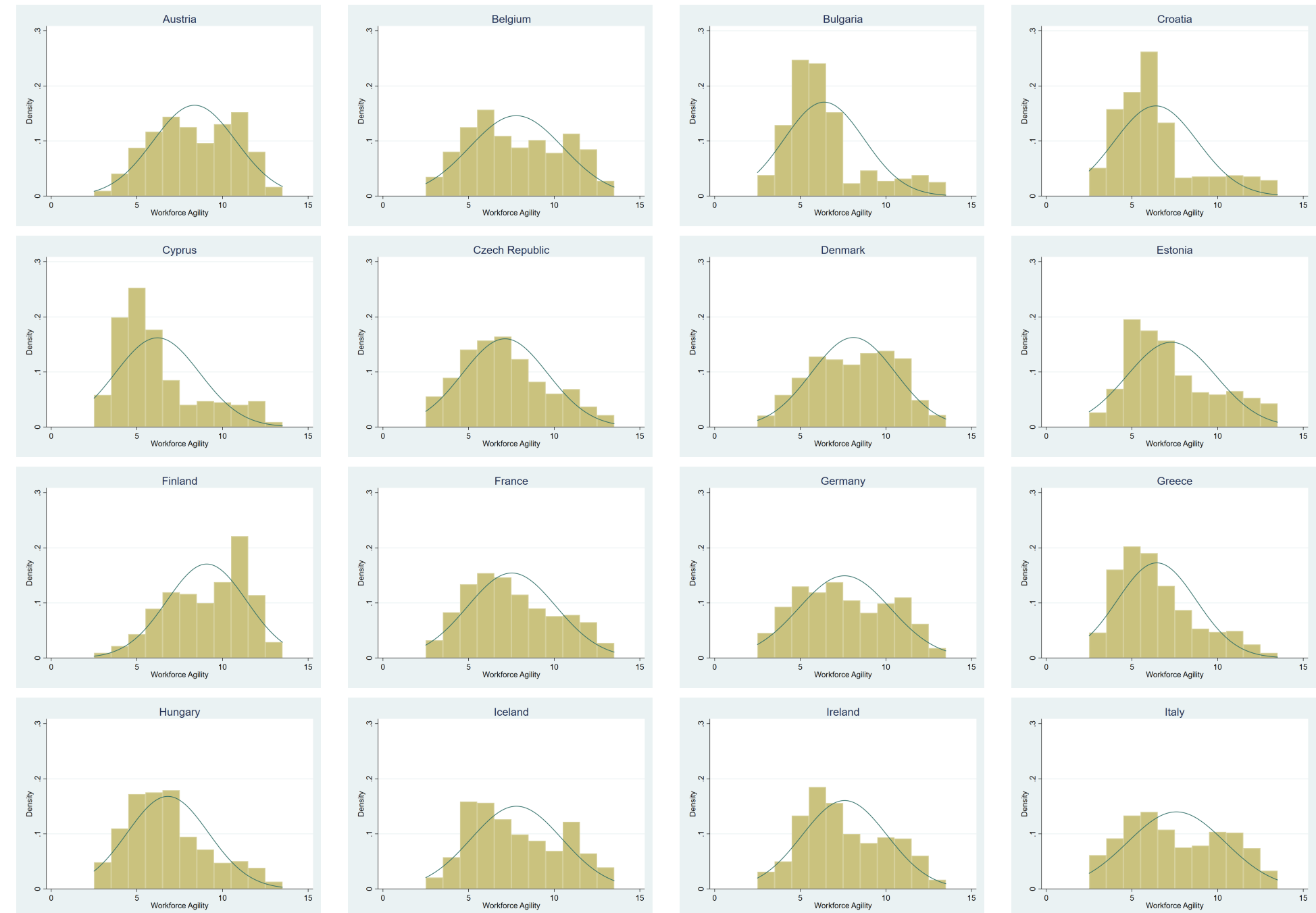

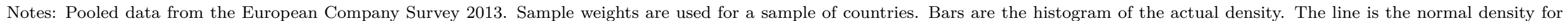
comparison. 
Figure 3: Heterogeneity of workforce agility across countries (second group).
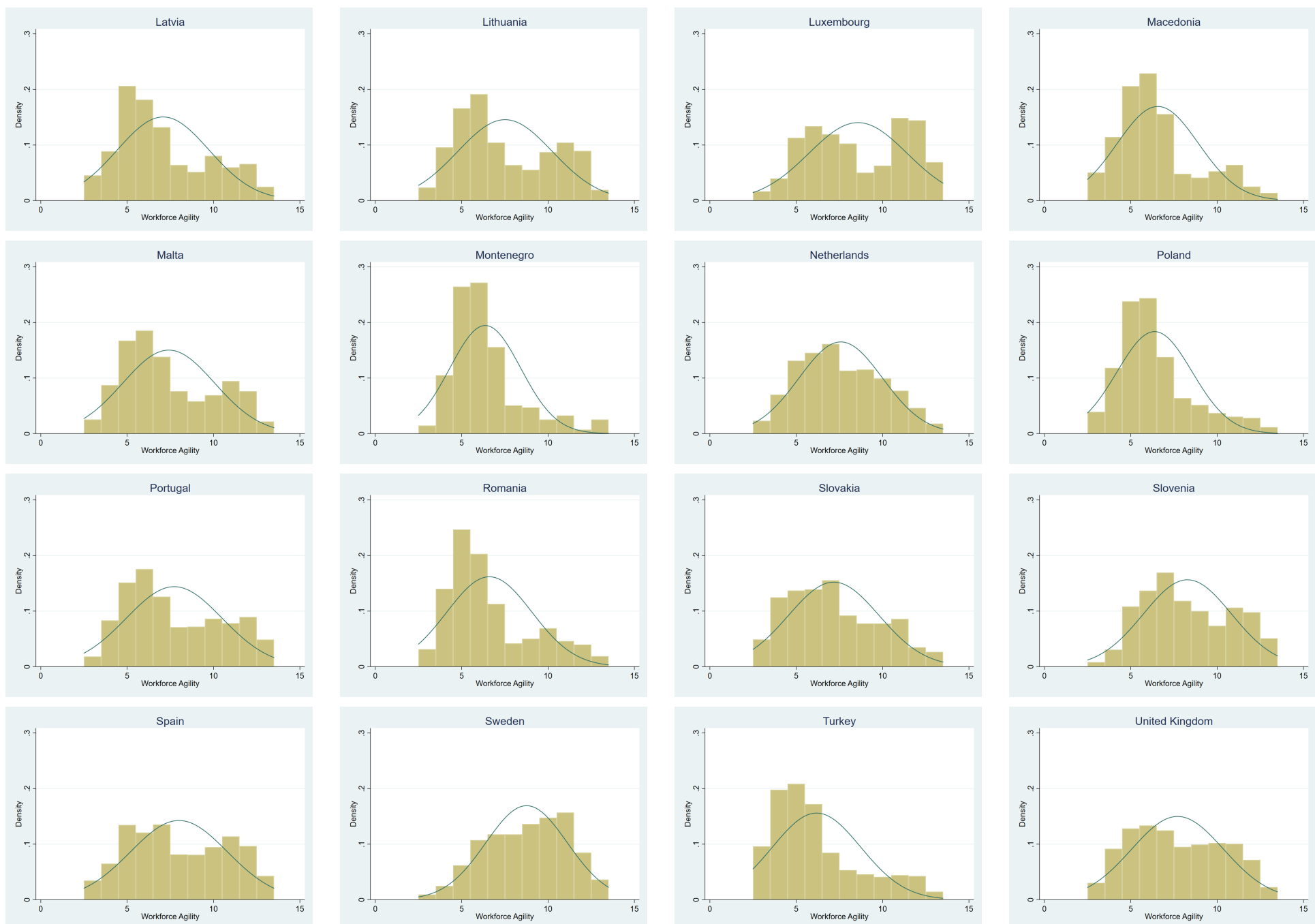

Notes: Pooled data from the European Company Survey 2013. Sample weights are used for a sample of countries. Bars are the histogram of the actual density. The line is the normal density for comparison. 
Figure 4: Workforce agility and innovation across countries.

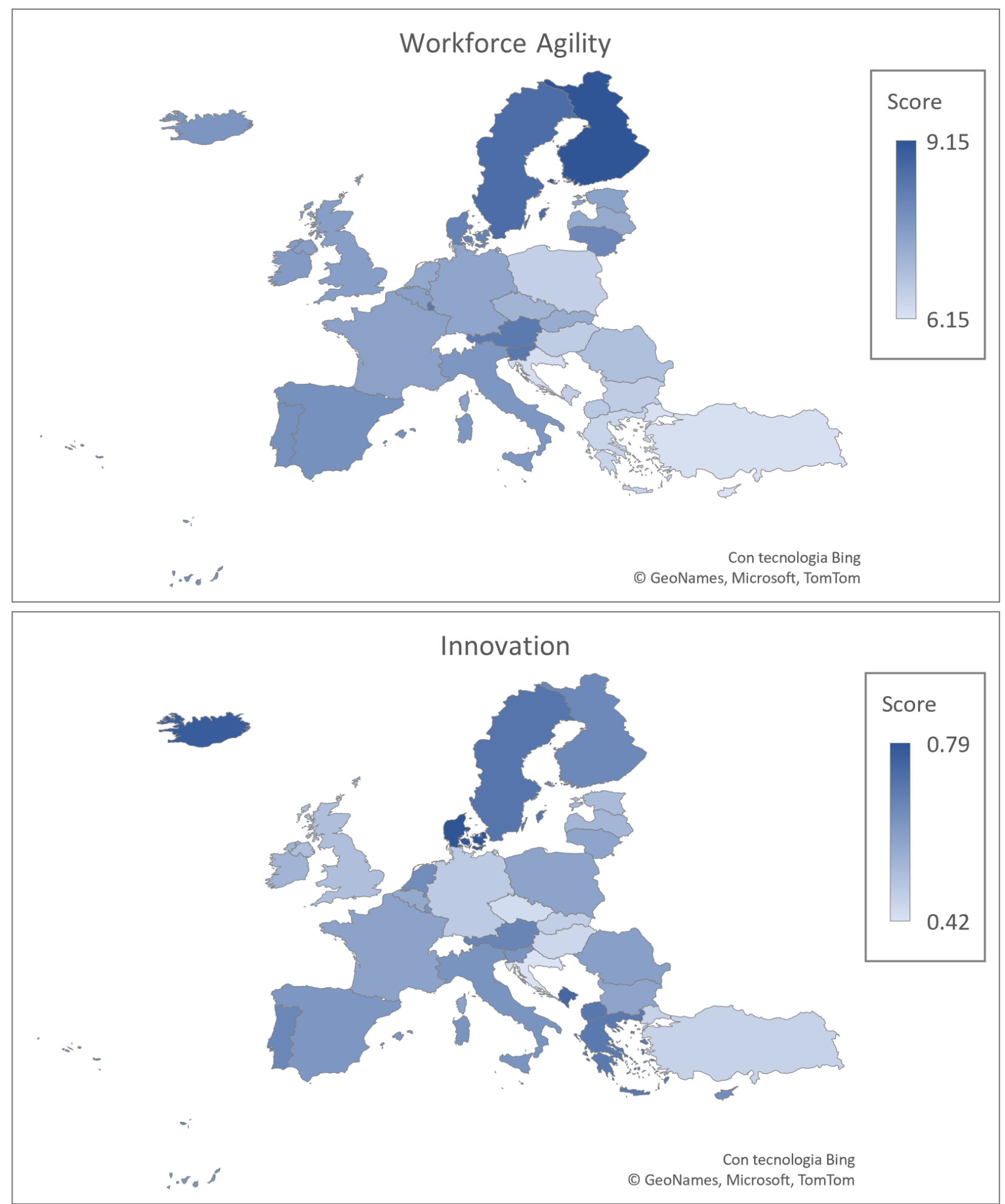

Notes: Pooled data from the European Company Survey 2013. Sample weights are used. The figure displays the country-level distribution of workforce agility and the introduction of any innovation, either product, process or organizational. 
Figure 5: Workforce agility, innovation and trust: correlations of country averages.

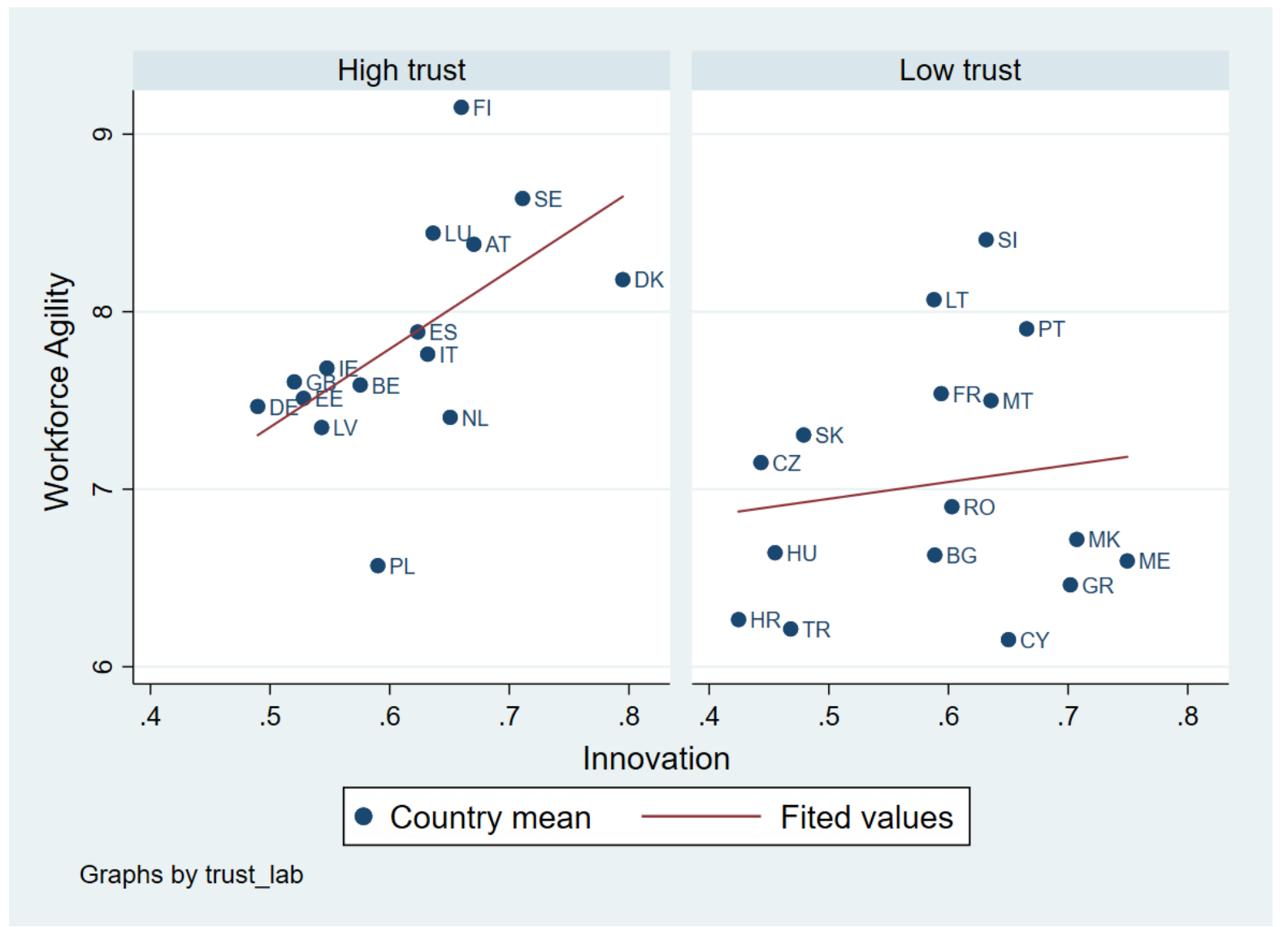

Notes: Pooled data from the European Company Survey 2013. Averages are taken across all firms within each country using sample weights. The figure displays the correlation between workforce agility and the introduction of any innovation, either product innovation, process innovation or organizational innovation. Country split is based on the perceived level trust as the percentage of people that agree or strongly agree with the statement: "generally speaking most people in our country can be trusted" (source: Eurobarometer 2018, expect for Turkey, Macedonia e Montenegro whose data are taken from the World Value Survey). High (low) trust countries are those with a trust level higher (lower) than the sample median (i.e. 39\%). 
Figure 6: Workforce agility of innovative firms and establishment characteristics.
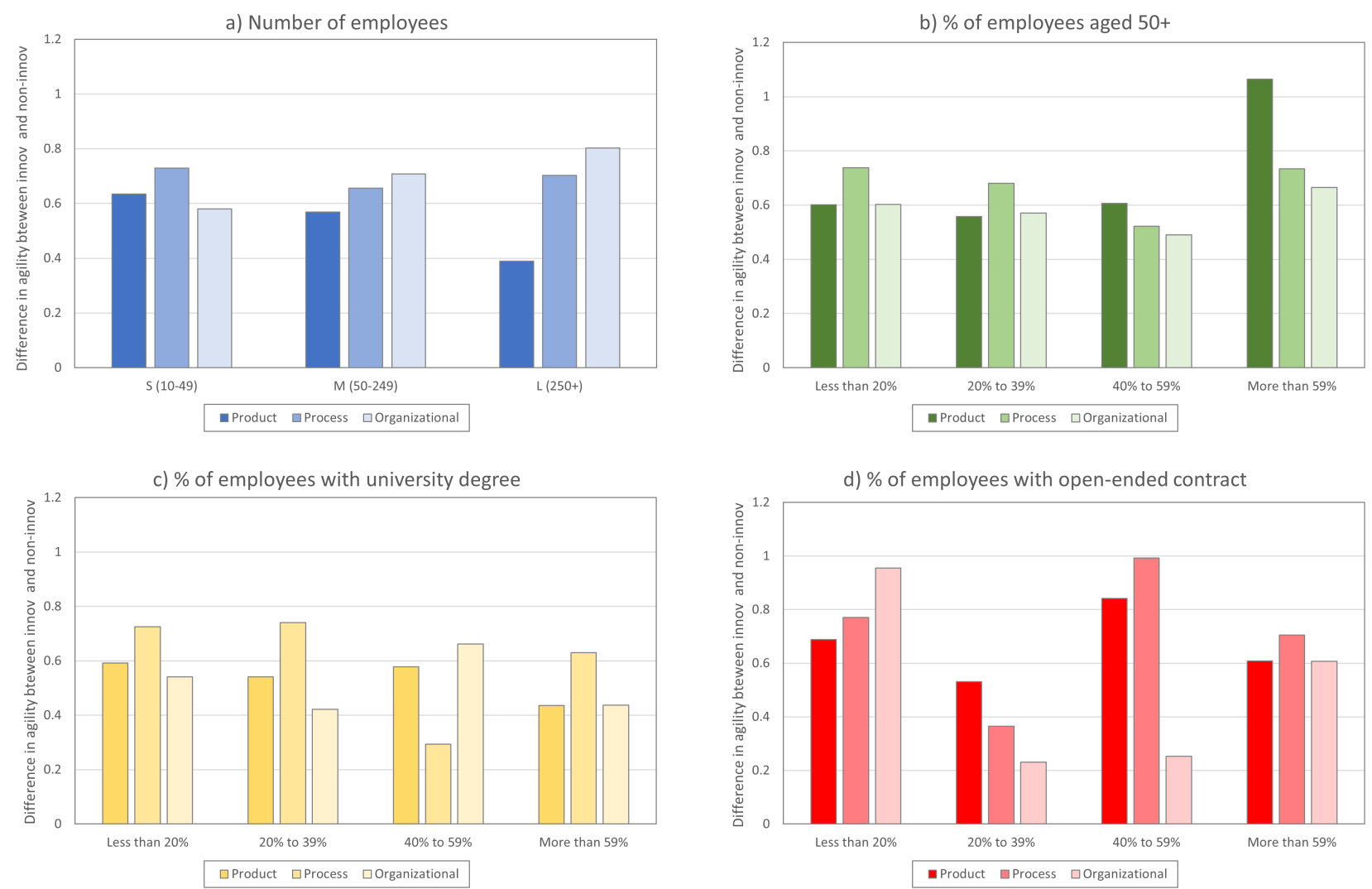

Notes: Pooled data from the European Company Survey 2013. Sample weights are used. Each graph reports on the vertical axis the difference of the workforce agility score between innovative and non-innovative establishments. 
Table 1: Descriptive statistics.

\begin{tabular}{lccccc}
\hline Variable & Obs & Mean & Std. Dev. & Min & Max \\
\hline Innovation & 27,019 & 0.657 & 0.475 & 0 & 1 \\
Product & 26,618 & 0.462 & 0.499 & 0 & 1 \\
Process & 26,534 & 0.425 & 0.494 & 0 & 1 \\
Organization & 26,754 & 0.428 & 0.495 & 0 & 1 \\
Old workforce & 25,910 & 0.677 & 0.861 & 0 & 3 \\
Women & 26,721 & 1.333 & 1.149 & 0 & 3 \\
High education & 25,326 & 0.788 & 1.090 & 0 & 3 \\
External search & 26,474 & 0.781 & 0.414 & 0 & 1 \\
Past technological change & 26,633 & 0.493 & 0.500 & 0 & 1 \\
Information System & 25,786 & 0.538 & 0.499 & 0 & 1 \\
Worse Finance & 27,019 & 0.273 & 0.445 & 0 & 1 \\
Outsourcing & 25,930 & 0.311 & 0.463 & 0 & 1 \\
Workforce Agility & 26,386 & 7.445 & 2.660 & 3 & 13 \\
Agility task & 26,562 & 4.072 & 1.098 & 2 & 6 \\
Agility time & 26,819 & 3.369 & 2.363 & 1 & 7 \\
\hline \hline
\end{tabular}

Notes: Pooled data from the European Company Survey 2013 
Table 2: Baseline regressions: Workforce agility and innovation.

\begin{tabular}{|c|c|c|c|c|c|c|c|c|}
\hline & $\begin{array}{c}(1) \\
\text { Innovation }\end{array}$ & $\begin{array}{c}(2) \\
\text { Product }\end{array}$ & $\begin{array}{c}(3) \\
\text { Process } \\
\end{array}$ & $\begin{array}{c}4) \\
\text { Organiz. }\end{array}$ & $\begin{array}{c}(5) \\
\text { Innovation }\end{array}$ & $\begin{array}{c}(6) \\
\text { Product }\end{array}$ & $\begin{array}{c}(7) \\
\text { Process } \\
\end{array}$ & $\begin{array}{c}(8) \\
\text { Organiz. }\end{array}$ \\
\hline Workforce Agility & $\begin{array}{c}0.032^{* * * *} \\
(0.004)\end{array}$ & $\begin{array}{c}0.030^{* * *} \\
(0.004)\end{array}$ & $\begin{array}{c}0.035^{* * *} \\
(0.004)\end{array}$ & $\begin{array}{c}0.022^{* * *} \\
(0.004)\end{array}$ & & & & \\
\hline Time Agility & & & & & $\begin{array}{c}0.018^{* * * *} \\
(0.004)\end{array}$ & $\begin{array}{c}0.019 * * * \\
(0.004)\end{array}$ & $\begin{array}{c}0.018^{* * *} \\
(0.004)\end{array}$ & $\begin{array}{c}0.010^{* *} \\
(0.004)\end{array}$ \\
\hline Task Agility & & & & & $\begin{array}{c}0.085^{* * *} \\
(0.009)\end{array}$ & $\begin{array}{c}0.0712^{* * *} \\
(0.008)\end{array}$ & $\begin{array}{c}0.098^{* * *} \\
(0.009)\end{array}$ & $\begin{array}{c}0.071^{* * *} \\
(0.009)\end{array}$ \\
\hline Small & $\begin{array}{c}-0.248^{* * *} \\
(0.023)\end{array}$ & $\begin{array}{c}-0.135^{* * *} \\
(0.023)\end{array}$ & $\begin{array}{c}-0.199^{* * * *} \\
(0.022)\end{array}$ & $\begin{array}{c}-0.291^{* * *} \\
(0.022)\end{array}$ & $\begin{array}{c}-0.239^{* * * *} \\
(0.023)\end{array}$ & $\begin{array}{c}-0.128^{* * *} \\
(0.022)\end{array}$ & $\begin{array}{c}-0.189^{* * * *} \\
(0.022)\end{array}$ & $\begin{array}{c}-0.284^{* * *} \\
(0.022)\end{array}$ \\
\hline Large & $\begin{array}{c}0.246^{* * *} \\
(0.034)\end{array}$ & $\begin{array}{c}0.135^{* * *} \\
(0.030)\end{array}$ & $\begin{array}{c}0.181^{* * *} \\
(0.031)\end{array}$ & $\begin{array}{c}0.276^{* * *} \\
(0.030)\end{array}$ & $\begin{array}{c}0.238^{* * *} \\
(0.034)\end{array}$ & $\begin{array}{c}0.130^{* * *} \\
(0.030)\end{array}$ & $\begin{array}{c}0.173^{* * *} \\
(0.031)\end{array}$ & $\begin{array}{c}0.269^{* * *} \\
(0.030)\end{array}$ \\
\hline External Search & $\begin{array}{c}0.343^{* * *} \\
(0.024)\end{array}$ & $\begin{array}{c}0.337^{* * *} \\
(0.025)\end{array}$ & $\begin{array}{c}0.374^{* * *} \\
(0.026)\end{array}$ & $\begin{array}{c}0.245^{* * *} \\
(0.025)\end{array}$ & $\begin{array}{c}0.334^{* * *} \\
(0.025)\end{array}$ & $\begin{array}{c}0.329^{* * *} \\
(0.025)\end{array}$ & $\begin{array}{c}0.364^{* * *} \\
(0.026)\end{array}$ & $\begin{array}{c}0.236^{* * *} \\
(0.025)\end{array}$ \\
\hline Past Technological Change & $\begin{array}{c}0.691^{* * *} \\
(0.020)\end{array}$ & $\begin{array}{c}0.557^{* * *} \\
(0.019)\end{array}$ & $\begin{array}{c}0.765^{* * *} \\
(0.020)\end{array}$ & $\begin{array}{c}0.520^{* * *} \\
(0.020)\end{array}$ & $\begin{array}{c}0.683^{* * *} \\
(0.020)\end{array}$ & $\begin{array}{c}0.551^{* * *} \\
(0.019)\end{array}$ & $\begin{array}{c}0.756^{* * *} \\
(0.020)\end{array}$ & $\begin{array}{c}0.513^{* * *} \\
(0.020)\end{array}$ \\
\hline Information System & $\begin{array}{c}0.260^{* * *} \\
(0.021)\end{array}$ & $\begin{array}{c}0.214^{* * *} \\
(0.020)\end{array}$ & $\begin{array}{c}0.306^{* * *} \\
(0.021)\end{array}$ & $\begin{array}{c}0.211^{* * *} \\
(0.020)\end{array}$ & $\begin{array}{c}0.250^{* * *} \\
(0.021)\end{array}$ & $\begin{array}{c}0.206^{* * *} \\
(0.020)\end{array}$ & $\begin{array}{c}0.294^{* * *} \\
(0.020)\end{array}$ & $\begin{array}{c}0.202^{* * *} \\
(0.020)\end{array}$ \\
\hline Worse Finance & $\begin{array}{c}0.0219 \\
(0.023)\end{array}$ & $\begin{array}{c}-0.038^{*} \\
(0.022)\end{array}$ & $\begin{array}{c}-0.045^{* *} \\
(0.022)\end{array}$ & $\begin{array}{c}0.083^{* * *} \\
(0.022)\end{array}$ & $\begin{array}{c}0.023 \\
(0.023)\end{array}$ & $\begin{array}{c}-0.038^{*} \\
(0.022)\end{array}$ & $\begin{array}{c}-0.044^{* *} \\
(0.023)\end{array}$ & $\begin{array}{c}0.084^{* * * *} \\
(0.022)\end{array}$ \\
\hline Outsourcing & $\begin{array}{c}0.207^{* * *} \\
(0.022)\end{array}$ & $\begin{array}{c}0.135^{* * *} \\
(0.021)\end{array}$ & $\begin{array}{c}0.177^{* * *} \\
(0.021)\end{array}$ & $\begin{array}{c}0.202^{* * *} \\
(0.021)\end{array}$ & $\begin{array}{c}0.200^{* * *} \\
(0.022)\end{array}$ & $\begin{array}{c}0.130^{* * *} \\
(0.021)\end{array}$ & $\begin{array}{c}0.170^{* * *} \\
(0.021)\end{array}$ & $\begin{array}{c}0.197^{* * *} \\
(0.021)\end{array}$ \\
\hline Old Workforce & $\begin{array}{c}-0.072^{* * *} \\
(0.012)\end{array}$ & $\begin{array}{c}-0.077^{* * *} \\
(0.012)\end{array}$ & $\begin{array}{c}-0.061^{* * * *} \\
(0.012)\end{array}$ & $\begin{array}{c}-0.065^{* * *} \\
(0.012)\end{array}$ & $\begin{array}{c}-0.072^{* * *} \\
(0.012)\end{array}$ & $\begin{array}{c}-0.077^{* * * *} \\
(0.012)\end{array}$ & $\begin{array}{c}-0.062^{* * * *} \\
(0.012)\end{array}$ & $\begin{array}{c}-0.065^{* * *} \\
(0.012)\end{array}$ \\
\hline Women & $\begin{array}{c}0.031^{* * *} * \\
(0.009)\end{array}$ & $\begin{array}{c}0.049^{* * *} \\
(0.009)\end{array}$ & $\begin{array}{c}0.037^{* * *} \\
(0.009)\end{array}$ & $\begin{array}{c}0.013 \\
(0.009)\end{array}$ & $\begin{array}{c}0.031^{* * *} \\
(0.009)\end{array}$ & $\begin{array}{c}0.049^{* * *} \\
(0.009)\end{array}$ & $\begin{array}{c}0.036^{* * *} \\
(0.009)\end{array}$ & $\begin{array}{c}0.013 \\
(0.009)\end{array}$ \\
\hline High Education & $\begin{array}{c}0.083^{* * *} \\
(0.011)\end{array}$ & $\begin{array}{c}0.089^{* * *} \\
(0.010)\end{array}$ & $\begin{array}{c}0.041^{* * *} \\
(0.010)\end{array}$ & $\begin{array}{c}0.085^{* * *} \\
(0.010)\end{array}$ & $\begin{array}{c}0.087^{* * *} \\
(0.011)\end{array}$ & $\begin{array}{c}0.092^{* * * *} \\
(0.010)\end{array}$ & $\begin{array}{c}0.046^{* * *} \\
(0.010)\end{array}$ & $\begin{array}{c}0.089^{* * *} \\
(0.010)\end{array}$ \\
\hline $\begin{array}{l}\text { Observations } \\
\text { Country + industry dummies } \\
\text { Model }\end{array}$ & $\begin{array}{l}20,023 \\
\text { Yes } \\
\text { Probit }\end{array}$ & $\begin{array}{l}19,906 \\
\text { Yes } \\
\text { Probit }\end{array}$ & $\begin{array}{l}19,888 \\
\text { Yes } \\
\text { Probit }\end{array}$ & $\begin{array}{l}19,926 \\
\text { Yes } \\
\text { Probit }\end{array}$ & $\begin{array}{l}20,023 \\
\text { Yes } \\
\text { Probit }\end{array}$ & $\begin{array}{l}19,906 \\
\text { Yes } \\
\text { Probit }\end{array}$ & $\begin{array}{l}19,888 \\
\text { Yes } \\
\text { Probit }\end{array}$ & $\begin{array}{l}19,926 \\
\text { Yes } \\
\text { Probit }\end{array}$ \\
\hline
\end{tabular}

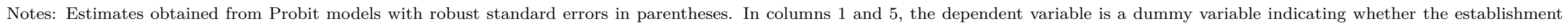

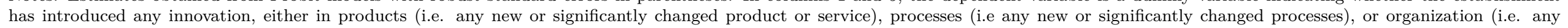

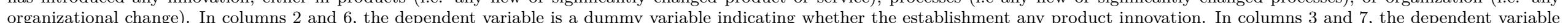

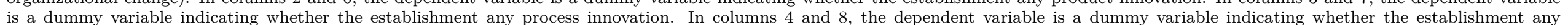
organizational innovation. ${ }^{* * *} \mathrm{p}<0.01,{ }^{* *} \mathrm{p}<0.05,{ }^{*} \mathrm{p}<0.1$. 
Table 3: Workforce agility and innovation: IV results.

\begin{tabular}{|c|c|c|c|c|c|c|}
\hline & $\begin{array}{c}(1) \\
\text { Product } \\
\text { [Second Stage] }\end{array}$ & $\begin{array}{c}(2) \\
\text { Workforce Agility } \\
\text { [First Stage] }\end{array}$ & $\begin{array}{c}(3) \\
\text { Process } \\
\text { [Second Stage] }\end{array}$ & $\begin{array}{c}(4) \\
\text { Workforce Agility } \\
\text { [First Stage] }\end{array}$ & $\begin{array}{c}(5) \\
\text { Organizational } \\
\text { [Second Stage] }\end{array}$ & $\begin{array}{c}(6) \\
\text { Workforce Agility } \\
\text { [First Stage] }\end{array}$ \\
\hline Workforce Agility & $\begin{array}{c}0.340^{* * *} \\
(0.013)\end{array}$ & & $\begin{array}{c}0.339^{* * *} \\
(0.014)\end{array}$ & & $\begin{array}{c}0.336^{* * *} \\
(0.013)\end{array}$ & \\
\hline Extra Pay & & $\begin{array}{c}0.203^{* * *} \\
(0.016)\end{array}$ & & $\begin{array}{c}0.202^{* * *} \\
(0.016)\end{array}$ & & $\begin{array}{c}0.202^{* * *} \\
(0.016)\end{array}$ \\
\hline Observations & 19,596 & 19,596 & 19,577 & 19,577 & 19,616 & 19,616 \\
\hline Country + industry dummies & Yes & Yes & Yes & Yes & Yes & Yes \\
\hline Establishment-level controls & Yes & Yes & Yes & Yes & Yes & Yes \\
\hline Workforce composition & Yes & yes & Yes & Yes & Yes & Yes \\
\hline Model & IV Probit & IV Probit & IV Probit & IV Probit & IV Probit & IV Probit \\
\hline
\end{tabular}

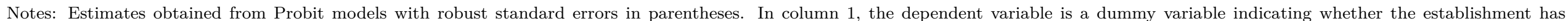

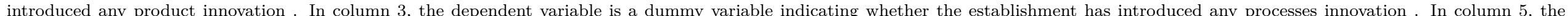

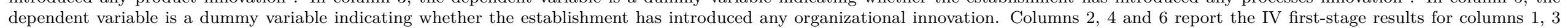

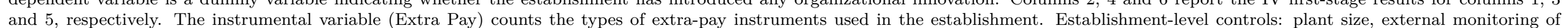

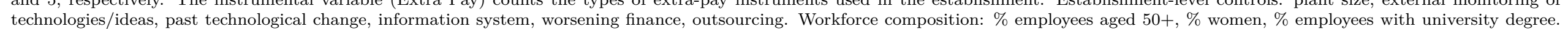
technologies/ideas, past technolog
$* * * \mathrm{p}<0.01,{ }^{* *} \mathrm{p}<0.05,{ }^{*} \mathrm{p}<0.1$ 
Table 4: Mechanisms: work climate, training, information sharing.

\begin{tabular}{lcccccc}
\hline & $(1)$ & $(2)$ & $(3)$ & $(4)$ & $(5)$ & $(6)$ \\
& Working Climate & Paid Training & Empl. Meetings & Info Dissem. & Sugg. Scheme & Empl. Survey \\
\hline \multirow{2}{*}{ Workforce Agility } & & & & & & \\
& & & & & & \\
& $(0.004)$ & $(0.004)$ & $(0.004)$ & $(0.004)$ & $(0.003)$ & $(0.004)$ \\
Observations & & & & & \\
Country + industry dummies & 21,778 & 21,826 & 21,753 & 21,758 & 21,719 & 21,673 \\
Workforce composition & Yes & Yes & Yes & Yes & Yes & Yes \\
Model & Yes & Yes & Yes & Yes & Yes & Yes \\
\hline \hline
\end{tabular}

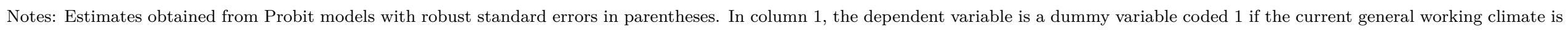

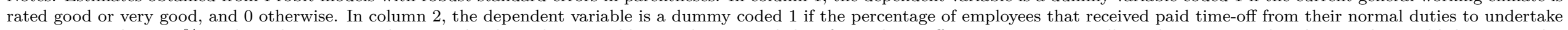

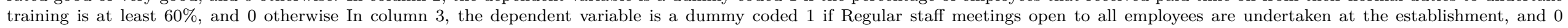

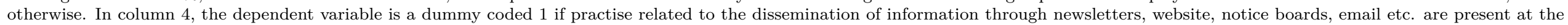

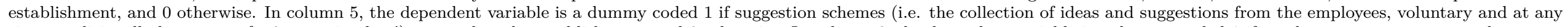

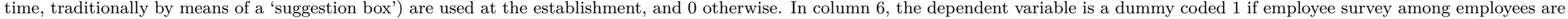
used at the establishment, and 0 otherwise. Workforce composition: $\%$ employees aged $50+, \%$ women, $\%$ employees with university degree. ${ }^{* * *} \mathrm{p}<0.01,{ }^{* *} \mathrm{p}<0.05,{ }^{*} \mathrm{p}<0.1$. 